\title{
SUSTAINABLE COUNSELLING VALUES BY INDONESIAN PRESCHOOL TEACHERS TO PREPARE MORE TOLERANT YOUNG GLOBAL CITIZENS
}

\author{
M. Solehuddin ${ }^{1}$
}

\begin{abstract}
Issues of intolerance in Indonesia, even involving children, have become the concerns of all related agencies, particularly those in children's education. Although character building has been mainstreamed in the national education system, little is known how preschool teachers contribute to the nurturance of tolerant young children as future global citizens. This study explores priority sustainable character values and their building strategies in counselling practices of pre-school teachers in West Java Province of Indonesia. Analysis of questionnaire, classroom observation and interview results by criteria of Global Citizenship Education (UNESCO, 2017) and character education in the $21^{\text {st }}$ century of Bialik, Bogan, Fadel and Horvathova (2015) show that counselling topics of the participating teachers have included sustainable values of global partnership, independence, nationalism, integrity, and religiosity exercised through individual and team works. By involving social agencies such as parents, principals, and religious leaders, teachers involved their students in various characterbuilding activities. The study also recommends more detail indicators and activities for teachers to improve their students' sense of tolerance as future global citizens.
\end{abstract}

Keywords: counselling for sustainable values, Indonesian preschool teachers, tolerant young global citizens

JOMSIGN: Journal of Multicultural Studies in Guidance and Counseling Website: http://ejournal.upi.edu/index.php/JOMSIGN

Permalink: http://ejournal.upi.edu/index.php/JOMSIGN/article/view/6314 How to cite (APA): Solehuddin, M. (2019). Sustainable Counselling Values by Indonesian Preschool Teachers to Prepare More Tolerant Young Global Citizens. JOMSIGN: Journal of Multicultural Studies in Guidance and Counseling, 3(2), 119-136.

This is an open-access article distributed under the terms of the Creative Commons Attribution 4.0 International License, which permits unrestricted use, distribution, and reproduction in any medium, provided the original work is properly cited.

\section{INTRODUCTION}

As a multicultural and predominantly Muslim society, Indonesia often experiences some incidents of intolerance including mass riot, youngster brawl, motorbike gangster, and terrorist acts. A few of these intolerance cases involve young people, including children. For instance, increasing terror

\footnotetext{
${ }^{1}$ Universitas Pendidikan Indonesia, Indonesia; msolehuddin@upi.edu
} 
incidents, which involve young people and children, in some major Indonesian cities like Jakarta and Surabaya during 2018, have become shocking phenomena (The Pikiran Rakyat Daily). This indicates how these young citizens are more susceptible to the negative influence they face in their social circles. Despite their involvement in terror incidents, these young people are, in fact, not considered the main actors but the victims in these intolerance activities. Children's innocence may have been misused by irresponsible adults for their own benefits.

In addition to intolerance, another issue the Indonesian government faces, along with the development of technology, is juvenile delinquency. Allured by its negative impact, children become more engaged in telecommunication device and tend to exhibit anti-social behaviours. They incline to uncritically copy and follow some negative lifestyles irrelevant with their cultural backgrounds, which are easily accessible online. In West Java area, for example, a group of young people have to regretfully die early 2018 because of overdosing illegally produced alcoholic drinks (The Pikiran Rakyat Daily, 2018). Similar embarrassing phenomena, including motorbike gangster and students' brawls, are easily identified in other parts of the country. Studies show that these violence and intolerance acts can be effectively addressed by building the character of young people (Cheng \& Ray, 2016; Blair \& Raver, 2015; Bialik, Bogan, Fadel \& Horvathova, 2015; Battistich, 2008). In this case, sustainable character building of young children is an important future investment. Young people should become critically empowered learners who are respectful of others, tolerant of difference and supporters of multiculturalism. As studies may have shown, properly empowered, they will even be able to be an active agent of change for sustainable development (von Braun, 2017).

Despite the significance of developing sustainable character values for young people, how it is related to the practice of children's counselling, particularly among Indonesian preschool children is still understudied. Considering the importance of nurturing tolerant young people as future global citizens, this research, therefore, examines the practice of counselling for sustainable character values among Indonesian preschool children. It specifically identifies priority character values in counselling practices and their implementation strategies so that Indonesia will have quality young demography bonus that can contribute to the development of the country in the future. 


\section{Sustainable character values}

Due to technology, people become more mobile, making the world smaller. Consequently, they will meet diverse people and, therefore, have to have more tolerance towards diversity. With the increasingly rapid information exchange, differences of race, religion, ethnicity and culture become more salient and that people should embrace rather than avoid this inevitable reality. Bearing in mind this increasing diversity, future world citizens like young children should have more sustainable character values for a more harmonious global life. For instance, in relation to global citizenship, children years 5-9 should be able to recognize sameness and difference of global citizens as well as show respect and appreciation for diversity (UNESCO Global Citizenship Education, 2015). These sustainable character values are keys to global life.

It seems that mere tolerance for diversity is insufficient. Serving as a basis for sustainability, it still needs supports. Since global life is more complex, Bialik et al. (2015) also add that future global citizens should have other such sustainable characters as mindfulness, curiosity, courage, resilience, ethics, and leadership (2015, p. ii). Of these aspects, the last three values; resilience, ethics and leadership, are considered more necessary for sustainable life on earth. For sustainability, people need to have stronger resilience on calamity and disaster, more ethical in invention and creativity, as well as have good leadership so that they can spread more peace on earth.

However, despite its necessity for sustainability, character building is a long process and needs time. Children need to be exposed to the process of character building from a very early age so that they will develop a good personality when they are grown up. This early exposure to character building is essential to prepare 'high-quality children' (Almerico, 2014; p. 1). He furthermore insists that future children should have qualities of generosity, kindness, honesty, tolerance, trust, integrity, royalty, fairness, freedom, equality, and respect of and for diversity. Other main characteristics young children should develop include discipline (Rahayuningsih \& Shilikhan, 2016), imagination (Richert, Shawber, Hoffman, \& Taylor, 2009), as well as honesty, responsibility, optimism, empathy and fairness (Alberta, 2005).

In practice, the character is a unique interrelation among knowledge, attitude and practices (KAP). Supporting this view, Lickona (1991) mentions three interrelated dimensions of moral as important parts of character; knowing, feeling and behaviour (p. 1). This means that to have sustainable 
characters, children need to have good knowledge of these character values and see real practices from their surroundings so that they can experientially feel and practice them in real life. This interrelation is important to have a successful and sustainable character development (Salas-Zapata, Rios-Osorio, \& Cardona-Arias, 2018). Without exemplary social figures, sustainable character values will end up being memorized without real practice.

Finally, the process of sustainable character values can be conducted in many ways. One of which is through counselling, especially among young children at pre-schools. In fact, the main purpose of counselling at this educational level should focus on building some foundational characters for young children (Bialik et al., 2015). Without this support, young people will not have sufficient development (Yuksel, Kucukoglu, Unsal, \& Salli, 2014) as it also becomes the foundation for lifelong learning (Bialik et al., 2015). These sustainable character values and how they are incorporated into the learning process may be identifiable from the counselling practices of Indonesian preschool teachers participating in this study.

\section{Teachers' professional development and counselling practice for sustainability}

Studies on teacher professional development have been conducted in different contexts, either for in-service or pre-service teachers. Some scholars, for instance, believe that in-service training for teachers is an effective way of sharing professional practices as well as a means of sustainable education (Kabadayi, 2016). He further explains that in the context of Turkey, in-service training for preschool teachers serves as a tool for professional development so that teachers can improve their knowledge and quality of teaching and learning for sustainable education. Considering its importance in supporting sustainable education, this aspect should become the priority in teacher professional development.

In-service professional development should enable teachers to prepare students to be responsible citizens. Considering the fast-changing social context which influences students' learning process, this task may be more challenging. To achieve this, teachers should adjust their conventional teaching method into a more transformative style of education (Bell, 2016) so that it can empower students to be more creative and adaptive to new changes. An example of this transformation is by integrating character values in various more thoughtful teaching activities like situation games and other interactive 
activities as Estonian preschool teachers have been practising (Ulavere \& Tammik, 2017). These teachers may believe that to be effectively implemented, moral values are not to be merely cognitively taught but comprehensively integrated into real practices.

In a more local context, the necessity of character education is considered important by the Indonesian government. In anticipation of intolerance incidents and juvenile delinquency, character education and building have become the backbone of the school curriculum. The Indonesian Presidential Decree No 87 year 2017 mentions some character values teachers should develop in their students which include religiosity, honesty, tolerance, discipline, hard work, creativity, independence, democracy, curiosity, nationalism, love for peace, reading, love for the environment, social care and responsibility. Of these characteristics, some are more emphasized by the issuance of Education Decree No 20 year 2018, which include religiosity, nationalism, integrity, independence, and social care.

Considering this emphasis on character building among young children, teacher education is also shifted to support character development. Both pre- and in-service teachers should be able to incorporate these sustainable character values into their teaching and learning process. Despite this emphasis on character building by teachers, little is known how teachers, particularly at preschools, incorporate these values in their counselling practices. Even in a developed country like the United States, only about nine per cent of preschool teachers incorporate characters in their teaching process (Kinkopf \& Casey, 2016). A similar phenomenon is also identified among Indonesian preschool teachers (Madihah, 2016). Therefore, this study also explores some sustainable character values Indonesian preschool teachers build and how they are incorporated into their counselling practices.

\section{METHOD}

To identify aspects of sustainable character values and their incorporation into preschool teachers' counselling practices, this study uses qualitative descriptive method (Frankfort-Nachmias, Nachmias, \& DeWaard, 2014; Creswell \& Poth, 2018). Involving 91 preschool teachers as participants selected from different regencies in West Java province of Indonesia, the main instrument of the study is questionnaire which identifies priority sustainable character values in counselling practices, teachers' strategies and steps in 
incorporating these aspects, parties involved in the counselling, as well as their counselling and learning activities. In addition to the questionnaire, the study also uses classroom observation to identify the counselling activities of developing sustainable character values and focus group discussion (FGD) to explore more details teachers' counselling practices as well as challenges they face in incorporating these values or elements into their teaching and counselling.

Prior to data collection, consent from participants was sought and participation in this study was voluntary. Findings were then analyzed on the basis of sustainable character values offered by Bialik, Bogan, Fadel and Horvathova (2015), UNESCO Global Citizenship Education (2015). Findings from the questionnaire, classroom observation and focus group discussion were then triangulated to identify sustainable character values incorporated into counselling practices and activities as well as strategies and challenges in its implementation.

\section{FINDINGS AND DISCUSSIONS}

This section combines findings and discussion presented on the basis of research questions. The first question asks prioritized sustainable characters values the participating pre-school teachers have incorporated into their counselling practices. Questionnaire findings reveal five main priority character values incorporated into counselling practices; religiosity, nationalism, integrity, independence, and partnership. Each of these sustainable values has certain indicators as described in Table 1.

Ranked in importance, the five sustainable character values are as follows; partnership or teamwork $(91.89 \%)$, integrity $(88.33 \%)$, independence $(86.66 \%)$, nationalism $(85.00 \%)$ and religiosity $(78.52 \%)$. As the table shows, each of these priority values has some indicators. First, for religiosity value, the practice of religious teaching is considered the most important indicator, followed by tolerance to different prayer practices of other religions and creating harmony among people of different religious affiliations. Second, nationalism is shown by loyal use of Bahasa Indonesia as the national language and participation in a regular flag ceremony. Third, integrity is indicated by honesty and responsibility, followed by the commitment to human values such as visiting sick friends, giving charity and asking an apology. Meanwhile, the value of independence is shown by self-assistance in 
food consumption, followed by self-assistance in drawing and other play activities, and being responsible for not littering and cleaning up after school activities. Finally, cooperation or partnership is indicated by appreciating group activities followed by a willingness to participate in teamwork like building house toys.

\section{Table 1}

Priority sustainable character values incorporated into counselling practices

\begin{tabular}{|c|c|c|c|}
\hline Sustainable & Indicators & Prior & evel (\%) \\
\hline \multirow[t]{3}{*}{ 1. Religiosity } & $\begin{array}{l}\text { a. Performing religious activities such as prayers, greetings, and } \\
\text { other religious terms for social interactions }\end{array}$ & 97.78 & \multirow{3}{*}{78.52} \\
\hline & $\begin{array}{l}\text { b. Showing tolerance to different religious practices and } \\
\text { affiliations }\end{array}$ & 82.22 & \\
\hline & $\begin{array}{l}\text { c. Maintaining harmony in the classroom of different religion } \\
\text { followers }\end{array}$ & 55.56 & \\
\hline \multirow[t]{2}{*}{ 2. Nationalism } & $\begin{array}{ll}\text { a. } & \text { Requiring preschool students to use correct Indonesian } \\
\text { language. }\end{array}$ & 87.78 & \multirow[b]{2}{*}{85.00} \\
\hline & $\begin{array}{l}\text { b. Showing loyalty to the country, e.g. attending flag ceremony } \\
\text { and singing the national anthem and other songs. }\end{array}$ & 82.22 & \\
\hline \multirow[t]{2}{*}{ 3. Integrity } & $\begin{array}{l}\text { a. Showing pledge to honesty and responsibility to school and } \\
\text { home activities }\end{array}$ & 96.67 & \multirow[b]{2}{*}{88.33} \\
\hline & $\begin{array}{l}\text { b. Showing commitment to humanity values such as visiting sick } \\
\text { friends, giving charity, and apologizing }\end{array}$ & 80.00 & \\
\hline \multirow[t]{3}{*}{ 4. Independence } & a. Showing independence in consuming foods and drinks & 93.33 & \multirow[b]{3}{*}{86.66} \\
\hline & b. Using their own potentials in drawing and other play activities & 82.22 & \\
\hline & $\begin{array}{l}\text { c. Showing responsibility such as dropping the rubbish into the } \\
\text { bins and cleaning up at the end of activities. }\end{array}$ & 84.44 & \\
\hline \multirow{2}{*}{$\begin{array}{l}\text { 5. Cooperation/ } \\
\text { partnership }\end{array}$} & a. Appreciating togetherness like playing together in groups & 98.22 & \multirow[b]{2}{*}{91.89} \\
\hline & $\begin{array}{l}\text { b. Showing a willingness to work together such as building } \\
\text { house toys and other team works }\end{array}$ & 85.56 & \\
\hline
\end{tabular}

The counselling values above are in line with more universal ones. They are relevant to the sustainable values of global citizenship education developed by UNESCO (2017), respect for difference. As Table 1 shows, to improve religiosity value, for instance, the participating teachers emphasize the importance of respect for different religious practices and affiliations as well as harmony among different followers of various religious affiliations. Similarly, integrity also focuses on showing commitment to humanity values such as visiting sick friends, giving charity, and apologizing. Meanwhile, the partnership also focuses on group plays and works among pre-schooler children.

Furthermore, the sustainable character values identified in this study are also relevant to those set in the national curriculum (Indonesian Ministry 
of National Education, 2017). As part of their professionalism, the participating teachers may have a good grasp of the direction of their national education goals, which emphasize the importance of sustainable character building. They have considered these five values as integral parts of the Indonesian Presidential Regulation Number 87 Year 2017 on character education, which also includes such other additional values as honesty, tolerance, discipline, hard work, creativity, democracy, curiosity, love for peace, reading habit, environmental and social care, and responsibility. These teachers have played their important roles in disseminating and implementing the presidential regulation on character education.

In addition, the emphasis of these character values in counselling practice also indicates teachers' high commitment for early and sustainable character building for children (Kinkopf \& Casey, 2016). Supporting this phenomenon, other scholars believe that these values are important in preparing preschool children prior to their enrolment at formal schooling at primary and secondary levels (Yuksel, Kucukoglu, Unsal \& Salli, 2014). These sustainable values serve as the foundation for character building and development. Once young children have developed these values, life will be more sustainable. For example, partnership, particularly at an international level, is necessary in today's more worldwide life for more global partnership and harmony.

However, it is interesting to note that, in practice, the participating teachers have different priorities from those determined by the national government. These preschool teachers tend to have more vibrant priority on sustainable character building. Although religious affiliation is very dominant in the life of Indonesians, interviews reveal that teachers do not consider religious value as the most important character value to impose on their students. Instead, they seem to have a more sustainable and universal understanding of character building by prioritizing values of cooperation or teamwork, integrity and independence as the three most important values in character building. One female teacher said,

Religion is important for our students, but they will live in a more global world. They need to work together with their friends from other countries. The friends have different religions and cultures. But, they have to live together on earth. $\underline{\text { So, cooperation with other children is more important. }}$ 
The participating teachers may believe that, while religious affiliation and nationalism are more local and exclusive, these first three values are more universal and inclusive compared to the first three values. Resonating Lickona (2017) on the process of character building, these teachers may believe that partnership and teamwork need to be developed through self-awareness and optimum efforts of improvement, followed by progress evaluation (p.1). These good character values should be embodied by all young children and become their inward motivation to perform the highest standard of behaviour in all situations. As future global citizens, young children should have exposure to values of universality and inclusiveness so that they can become more openminded and tolerant future global citizens and leaders. These three most prioritized values are essential for developing a more sustainable global life in the future.

In addition, it is also interesting to note that religiosity is understood as more than ritual. As table 1 shows, indicators or religiosity include performing religious activities such as prayers, greetings, and other religious terms for social interactions. Instead of only focusing on these ritual prayers, religiosity should be applied in more universal values, without diminishing the importance of religious rituals. However, young children should not only understand religiosity as ritual prayers but also beyond that, applicable in other sustainable values such as cleanliness, natural reservation, and animal love. They should be aware that making friends with those from different religious affiliations, ethnicities and cultural backgrounds is an essential part of religious teaching.

The next issue the questionnaire addresses is counselling strategy. Two strategies have been identified; group and individual. Each of which has some activities as described in Table 2 below.

Table 2

Pre-school Teachers' Counselling Strategies

\begin{tabular}{|c|c|c|}
\hline Strategy & Identified activities of counselling for character building & Percentage \\
\hline Group & 1. Group play & 54.44 \\
\hline
\end{tabular}




\begin{tabular}{|c|c|c|}
\hline \multirow[t]{6}{*}{ Strategy } & 2. Social talks & 22.22 \\
\hline & 3. Storytelling & 12.22 \\
\hline & 4. Angle learning & 15.56 \\
\hline & 5. Playing puzzle and house & 13.33 \\
\hline & 6. Teamwork & 15.56 \\
\hline & 7. Playing with a group numbering & 10.00 \\
\hline \multirow{8}{*}{$\begin{array}{l}\text { Individual } \\
\text { strategy }\end{array}$} & 1. Guided individual learning & 50.00 \\
\hline & $\begin{array}{l}\text { 2. Use of media, tools, learning strategy, and learning/working } \\
\text { time }\end{array}$ & 15.56 \\
\hline & 3. Toilet training for self-hygiene & 15.56 \\
\hline & 4. Independent individual assignment & 10.00 \\
\hline & $\begin{array}{l}\text { 5. Individual assignment in a classical setting, when students } \\
\text { are individually asked to take a turn reading Qur'an, others } \\
\text { are assigned to draw pictures. }\end{array}$ & 12.22 \\
\hline & $\begin{array}{l}\text { 6. Disciplined behaviour practices such as on-time arrival, tidy } \\
\text { eating, and cleaning up the learning tools. }\end{array}$ & 13.33 \\
\hline & 7. Behaviour practices based on everyday experiences & 10.00 \\
\hline & 8. Working together with parents (parenting) & 12.22 \\
\hline
\end{tabular}

Based on the table, of the seven activities in group-strategy, group play ranks the highest (54.44), followed by social talks (22.22), angle learning (15.56), and teamwork (15.56), whereas playing with group numbering places the lowest (10.00). Meanwhile, among eight activities of individual strategy, guided individual learning ranks the highest (50.00) followed by the use of media, tools (15.56) and toilet training (15.56) whereas independent individual assignment (10.00) and behaviour practices based on everyday experiences (10.00) are the two lowest.

Based on the table, it seems that these two identified strategies support the findings of previous studies on counselling practices among young children. Most scholars agree that character building for preschool students are best conducted in both group and individual strategies (Lickona, 1991, 2007; Kusnarto, Saraswati, \& Nugraheni, 2016). However, of these two strategies, teamwork or group strategy is considered more effective in children's counselling of character building (Battistich, 2008) whereas only a few studies agree that individual strategy is more beneficial for developing children's character building (Richert, Shawber, Hoffman, \& Taylor, 2009). It is 
necessary to note that group or social skills are considered more necessary in this global life where the partnership is more preferable than the competition.

The next issue in counselling practice the study addresses is an agency. Findings show three agencies involved in this process; parents, principals, and community figures with their different roles as shown in Table 3 ranked in importance.

Table 3

Agencies involved in preschool children counselling

\begin{tabular}{|c|c|c|}
\hline $\begin{array}{l}\text { Agencies } \\
\text { involved }\end{array}$ & Roles of each party involved & Percentage \\
\hline \multirow[t]{5}{*}{ Parents } & $\begin{array}{l}\text { 1. Becoming teachers' partners in children's character } \\
\text { building }\end{array}$ & 53.33 \\
\hline & 2. Directing children's character building & 17.78 \\
\hline & $\begin{array}{l}\text { 3. Conditioning children for a comprehensive counselling } \\
\text { (physical and emotional). }\end{array}$ & 20.00 \\
\hline & 4. Continuing children's character building at homes & 16.67 \\
\hline & $\begin{array}{l}\text { 5. Conditioning children to practice good character at } \\
\text { homes }\end{array}$ & 12.22 \\
\hline \multirow[t]{5}{*}{$\begin{array}{l}\text { Preschool } \\
\text { principals }\end{array}$} & $\begin{array}{l}\text { 1. Resource persons for parents and teachers in preschool } \\
\text { children's character building }\end{array}$ & 14.44 \\
\hline & 2. Guides in preschool children's character building & 18.89 \\
\hline & $\begin{array}{l}\text { 3. Teacher's partner in the character development of } \\
\text { preschool children }\end{array}$ & 14.44 \\
\hline & $\begin{array}{l}\text { 4. Together with teachers, developers of character-building } \\
\text { curriculum }\end{array}$ & 13.33 \\
\hline & $\begin{array}{l}\text { 5. Policy developers in the character development of } \\
\text { preschool children }\end{array}$ & 12.22 \\
\hline \multirow{2}{*}{$\begin{array}{l}\text { Community } \\
\text { figures }\end{array}$} & 1. Professionally practising teachers & 16.67 \\
\hline & 2. Environment to develop preschool children's characters & 11.11 \\
\hline
\end{tabular}

In addition to the order of importance, the percentage of roles also shows significance. The first and most important agency, parent, has five roles, with the highest percentage of 'becoming teachers' partners in children's character building' (53.33). The second agency is a school principal, with 'guides in preschool children's character building' (18.89) as the highest percentage. The last agency is community figures, with only two roles, and the highest percentage is professional teachers (16.67).

Based on this data, it reveals that the involvement of related agencies in developing sustainable children character values is necessary. As the proverb goes, raising a child needs a village, developing sustainable character 
values in children also needs the supports from all three relevant and essential agencies (Lickona, 2017) who can provide emotional supports for the development of children's sustainable character values (Leithwood \& Beatty, 2008). However, the presence of these agencies is not without requirement. Teachers should make sure that each agency can do their best to support the process of sustainable character development (Bialik et al., 2015). Without which, this practice will not be fruitful and empowering. In the Indonesian context, this three-party agency is also strengthened by the ministerial regulation No. 20 Year 2018, emphasizing that counselling and learning practices at preschools are conducted within intra-curricular and intercurricular activities, by involving all relevant agencies such as schools, parents, and the community at large.

Educating young children, including the development of sustainable characters, need time and support from all relevant agencies. Of these agencies, parents seem to be the most important partner for teachers. Without ignoring the importance of school principals and community figures, parents serve as the strongest support for developing young children's sustainable characters as children live longer with their parents at homes than with teachers/principals at schools or community. For this, teachers' good communication and partnership with parents will determine the success of character building in children (Kinkopf \& Casey, 2016). In fact, the responsibility for educating children lies with parents. In this case, teachers are outsourcing human resource hired by parents who do not have sufficient capacity to educate their own children.

Furthermore, counselling practice for sustainable character values has three stages; preparation, implementation and evaluation. During the first stage, teachers assess students' needs prior to program development, to make sure that the designed counselling program matches the needs of students. Meanwhile, implementation has seven activities, starting from habituation to reflection. Finally, the process ends with the evaluation of process and output and suggests future action. Table 4 below provides more detail information about the stages of counselling practice.

Table 4

Stages of counselling for sustainable character values

\begin{tabular}{lll}
\hline Preparation & 1. Assessment of children's needs & 10.00
\end{tabular}




\begin{tabular}{|c|c|c|}
\hline & 2. Program development & 10.00 \\
\hline \multirow[t]{7}{*}{ Implementation } & 1. Learning habituation for children & 13.33 \\
\hline & $\begin{array}{l}\text { 2. Appreciation (certificate) presented to children at the end } \\
\text { of the semester }\end{array}$ & 11.11 \\
\hline & $\begin{array}{l}\text { 3. Familiarizing children to volunteer works (cleaning } \\
\text { inside and outside classrooms) }\end{array}$ & 11.11 \\
\hline & $\begin{array}{l}\text { 4. Providing positive and negative examples through } \\
\text { storytelling }\end{array}$ & 10.00 \\
\hline & 5. Continuous counselling on a daily basis & 16.67 \\
\hline & 6. Storytelling on God and His creation to grow religiosity & 13.33 \\
\hline & 7. Reflective activities & 10.00 \\
\hline \multirow[t]{3}{*}{ Evaluation } & 1. Process evaluation & 10.00 \\
\hline & 2. Output evaluation & 13.33 \\
\hline & 3. Further action & 11.11 \\
\hline
\end{tabular}

The stages of counselling the participating teachers have been practising have sound justification. Many scholars support the use of these stages, believing that agreement to this process supported by teachers' creativities make counselling practices and learning more empowering and successful (Hall, Kaduson, \& Schaefer, 2002; Aram \& Shlak, 2008; Isjoni, 2010). Complying with stages, for example, teachers planning storytelling have to build rapport with children, prepare the setting, media, build students' knowledge of the field, deliver topics of discussion and finally, together with students, reflect on the session.

Finally, counselling for sustainable character buildings can be performed in various activities. To achieve this purpose, teachers can involve students in various learning activities such as angle area, outdoor activities, project-based learning, and other specific activities as shown in Table 5. Each of these activities has different details with different percentage of importance.

\section{Table 5}

Activities of character building counselling for preschool children

\begin{tabular}{lllc}
\hline \multicolumn{1}{c}{ Activities } & \multicolumn{1}{c}{ Details } & Percentage \\
\hline $\begin{array}{l}\text { 1. Angle area } \\
\text { learning }\end{array}$ & a. & $\begin{array}{l}\text { Angle learning for building children's cooperation or } \\
\text { teamwork }\end{array}$ & 14.44 \\
\cline { 2 - 3 } & b. & Block stacking learning & 15.56 \\
\cline { 2 - 3 } & c. & Learning about nature, divinity, culture, development, \\
& & 13.33 \\
& & and family & 12.22 \\
\cline { 2 - 3 } & d. & Angle or corner learning, divinity, and literacy & \\
\hline
\end{tabular}




\begin{tabular}{|c|c|c|}
\hline & e. Learning of areas like corner & 11.11 \\
\hline \multirow{4}{*}{$\begin{array}{l}\text { 2. Outdoor } \\
\text { learning }\end{array}$} & a. Applied learning & 16.67 \\
\hline & b. Leisure with nature & 13.33 \\
\hline & c. Free or unguided learning & 10.00 \\
\hline & d. Out of classroom learning & 13.33 \\
\hline \multirow[t]{3}{*}{$\begin{array}{l}\text { 3. Project-based } \\
\text { learning }\end{array}$} & $\begin{array}{l}\text { a. Students' design of the process to solve certain } \\
\text { problems }\end{array}$ & 15.56 \\
\hline & $\begin{array}{l}\text { a. Developing students' characters of cooperation, } \\
\text { friendship, and responsibility for task completion }\end{array}$ & 10.00 \\
\hline & $\begin{array}{l}\text { b. Colouring pictures about issues related to cooperation } \\
\text { of teamwork }\end{array}$ & 11.11 \\
\hline \multirow{5}{*}{$\begin{array}{l}\text { 4. Specific } \\
\text { activities }\end{array}$} & a. Knowledge building & 34.44 \\
\hline & b. Natural learning & 11.11 \\
\hline & c. Playing & 18.89 \\
\hline & d. Conditioning or habituating in daily activities & 12.22 \\
\hline & $\begin{array}{l}\text { e. Counselling for children who need special assistance } \\
\text { in character building }\end{array}$ & 16.67 \\
\hline
\end{tabular}

Teachers have their own priority activities. In angle learning, most teachers prefer block-stacking learning, whereas for outdoor activities they like applied learning. In addition, most teachers believe that providing a solution to problems is the most important aspect of project-based learning whereas, for specific activities, they consider knowledge building as the most important activity. As Tables 4-5 show, the participating teachers have implemented transformative teaching by incorporating sustainable character values in creative individual/group and indoor/outdoor activities (Bell, 2016) including situation games and other interactive activities, as practiced by Estonian teachers (Ulavere \& Tammik, 2017) to provide more comprehensive knowledge, attitude and practice (KAP) of sustainable character values.

Finally, the participating teachers also still have some challenges in their counselling practices due to some reasons. First, not all teachers have a good comprehension of sustainable character values so that they may not be able to comprehensively transfer these values to their students. Second, sustainable global citizenship value needs further confirmation. Since the participating teachers and students are predominantly followers of Islam, their tolerance for people of different religious affiliations need to be proven in more religiously and culturally diverse community engagement. Third, developing creative counselling activities need sufficient financial supports. Otherwise, teaching will be monotonous, boring, and less effective. 


\section{CONCLUSIONS AND RECOMMENDATIONS}

Based on the discussion above, this study comes with several conclusions. First, some priority sustainable character values incorporated in counselling practices include religiosity, nationalism, integrity, independence, and global engagement. Mainstreamed in the national education system Indonesia, these values are also important aspects of UNESCO's global citizenship education. Second, these character values are developed through both individual and group strategies. While group works include sharing ideas, storytelling, angle learning, puzzles, and number games, individual strategies comprise guided individual assignment, toilet training, and parenting. Third, to empower the counselling practices, teachers involve social agencies of parents, school principals, and community figures. Since parents serve as teachers' partners who help guide children at homes, principals cooperate with teaches as resource persons, guides, and partners in developing policies for children's character building. Meanwhile, community figures work as guardians who provide social supports for the development of children's sustainable characters. Next, counselling practice has three stages; preparation which includes program assessment and development, implementation, including learning habituation, appreciation, giving examples, storytelling, and reflection, and finally, evaluation which includes process, output and further action.

However, findings may have limited significance as the study only focuses on the counselling practices among preschool teachers, which may not represent counselling practices among higher age levels such as primary and secondary schools. This survey study may also not describe in-depth account of teachers' counselling practices. As such, future studies should include a higher level of students and more qualitative instruments for a deeper analysis of sustainable character-building strategies and values among young Indonesians.

The study also recommends that preschool teachers prioritize five aforementioned sustainable character values in their counselling practices while identifying other values considered necessary for children's character building. Teachers are also encouraged to combine both group and individual strategies in various play activities by inviting principals and community figures as collaborating agencies. Finally, further studies should also identify counselling practices for a higher level of schooling, primary and secondary, 
so that more young Indonesians are exposed to values of tolerance so that they will become more open-mind global citizens.

\section{REFERENCES}

Alberta. (2005) The heart of the matter : character and citizenship education in Alberta schools. Alberta Education Cataloguing in Publication Data: Canada.

Almerico, G. M. (2014). Building character through literacy with children literature. Research in Higher Educational Journal, 26, 1-9.

Aram, D. \& Shlak, M. (2008). The safe kindergarten: Promotion of communication and social skills among kindergartners. Early Education And Development Journal, 19 (6), 865-884.

Bell, D. V. J. (2016). Twenty first century education: Transformative education for sustainability and responsible citizenship. Journal of Teacher Education for Sustainability, 18 (1), 48-56.

Battistich, V. (2008). Character education, prevention, and positive youth development. Journal of Character Education, 6, 1-9.

Bialik, M., Bogan, M., Fadel, C., Horvathova, M. (2015). Character education for the 21st century: What should students learn? Massachusetts: Center for Curriculum Redesign Boston.

Blair, C., \& Raver, C. C. (2015). School readiness and self-regulation: A developmental psychobiological approach. Annual Review of Psychology, 66, 711-731. http://dx.doi.org/10.1146/annurev-psych010814015221.

Cheng, Y. \& Ray, D. C. (2016). Child-centered group play therapy: Impact on social-emotional assets of kindergarten children. The Journal for Specialists in Group Work, 41 (1), 209-237.

Creswell, J. W. \& Poth, C. N. (2018). Qualitative inquiry \& research design: Choosing among five approaches ( $4^{\text {th }}$ edition). Los Angeles: SAGE.

Frankfort-Nachmias, C., Nachmias, D. \& DeWaard, J. (2014). Research methods in the social sciences ( $8^{\text {th }}$ edition). New York: Worth Publishers.

Hall, T.M., Kaduson, T.D., Schaefer, C.E. (2002). Fifteen Effective Play Therapy Techniques. Journal of American Psychological Association, Inc. 2002, 33 (6), 515-522. 
Isjoni. (2010). Model pembelajaran anak usia dini (Learning model for young children). Bandung. Indonesia: Alfabeta.

Kabadayi, A. (2016). A suggested in-service training model based on Turkish preschool teachers' conceptions for sustainable development. Journal of Teacher Education for Sustainability, 18 (1), 5-15.

Kinkopf, T. M. \& Casey, C. (2016). Character education: Teachers' perceptions of its implementation in the classroom. Journal of Education, Delta State University, 6, 4-5.

Kusnarto, K., Saraswati, S., Nugraheni, E.P. (2016). Implementasi Pelayanan Bimbingan dan Konseling di Sekolah Dasar Negeri dan Swasta se Kecamatan Gunung Pati Kota Semarang (Prosiding Konvensi Nasional XIX ABKIN), PB ABKIN : Banjarmasin.

Leithwood, K. \& Beatty, B. (2008). Leading with Teacher Emotions in Mind. London: Corwins Press.

Lickona, T. (2017). Help kids and adults take responsibility for building their own character. Cortland Education Journal, 2, 1-9.

M.Yuksel, Kucukoglu Fatma Ozge UNSAL, and Duygu SALLI (2014). The DevelopmentAnd Implementation Of A Guidance Counseling Program Aiming To Support 54-66 Months Old Children's Development Level And Readiness For Primary School, International Journal on New Trends in Education and Their Implications www.ijonte.org

Madihah, H. (2016). Penerapan Pendidikan Karakter (The implementation of character education). Proceeding of National Convention XIX. Banjarmasin: PB ABKIN.

Peraturan Presiden (Perpres) Nomor 87 Tahun 2017. Tentang Penguatan Pendidikan Karakter.

Peraturan Menteri Pendidikan dan Kebudayaan Republik Indonesia Nomor 20 Tahun 2018 tentang Penguatan Pendidikan Karakter pada Satuan Pendidikan Formal

Rahayuningsih, S. \& Sholikhan. (2016). Disciplinary character education at early age. IOSR Journal of Research \& Method in Education (IOSRJRME), 6, 42-49.

Richert, R.A., Shawber, A.B., Hoffman, R.E., and Taylor, M. (2009). Learning From Fantasy and Real Characters in Preschool and 
Kindergarten. Journal of Cognition and Development, Taylor \& Francis Group, 10, 41-66.

Salas-Zapata, W. A., Rios-Osorio, L. A. \& Cardona-Arias, J. A. (2018). Knowledge, attitudes, and practices of sustainability: Systematic review 1990-2016. Journal of Teacher Education for Sustainability, 20 (1), 46-63.

The Pikiran Rakyat Daily, December 2018.

Ulavere, P. \& Tammik, A. (2017). Value education in Estonian preschool child-care institutions. Journal of Teacher Education and Sustainability, 19 (1), 129-146.

UNESCO global citizenship education, topics and learning objectives (2015).

von Braun, J. (2017). Children as agents of change for sustainable development. In A. M. Battro et al., (Eds.) Children and sustainable development, (pp. 17-30). New York: Springer International Publishing. DOI 10.1007/978-3-319-47130-3_2 